\title{
CITIC Guoan Financial Fraud Case Analysis
}

\author{
-- Reflections on Business Ethics and Accounting Professional Ethics
}

\author{
Rui Deng ${ }^{1, *}$, Liang Mao \\ ${ }^{1}$ Management institute, Sichuan university of Science and engineering, Yibin, 644005, China \\ ${ }^{2}$ Management institute, Associate Professor, Sichuan university of Science and engineering, Yibin, 644005, China
}

\begin{abstract}
With the diversified development of contemporary China 's economy, the rapid growth of high-quality economy, but fraud occurs frequently, emerge in endlessly. This paper introduces the theoretical knowledge, reviews the case of CITIC Guoan, and expounds the background and fraud situation of the company. Then through the analysis of CITIC Guoan ' s financial fraud cases of A-share listed companies for seven consecutive years, this paper comprehensively summarizes the means of fraud from six aspects, triggering the thinking of business ethics and accounting professional ethics. Finally, from the staff, management and external supervision and management of listed companies to prevent financial fraud recommendations.
\end{abstract}

Keywords: Business ethics, Accounting professional ethics, Financial fraud.

\section{Introduction}

Today, China is in a great change that has not happened in a century, and China is facing unprecedented shocks and challenges. Since the reform and opening up, China 's GDP has grown rapidly and entered a new era. However, due to high-quality economic growth, a small group of criminals risked for their own private interests. Internationally, financial frauds such as Enron and Lehman Brothers events, and domestic financial frauds such as Yinguangxia and Zhangzidao events occur frequently and emerge in an endless stream. The means and methods of financial fraud are various, and there are many loopholes but the essence is to violate the national and public interests. In order to prevent the occurrence of financial fraud, China has formulated and implemented a series of rules and regulations, such as " Accounting Law, " " Accounting Basic Work Norms, " " Accounting Standards, " but there are still many top-notch enterprises to try.

Why is there a phenomenon of repeated prohibitions, 'former servant succession'? The author believes that in addition to rules and regulations, enterprises should be guided to consciously and unconsciously abide by business ethics and accounting professional ethics, so that they do not dare to falsify, do not falsify, can not falsify. To follow the business ethics and accounting professional ethics, promote the sustained, stable and healthy development of enterprises, leading fairness and integrity. This paper analyzes the typical cases of CITIC Guoan financial fraud, analyzes its means, and the resulting business ethics and accounting professional ethics issues.

\section{Business Ethics and Accounting Ethics}

People are social people, must abide by the social public order and good customs. Although an enterprise is an organization, in China, it is a "legal person" established through registration, an economic entity that achieves its business objectives through people, and a personification economic person". Therefore, there is also compliance with business ethics and accounting professional ethics.

\subsection{Business Ethics}

The so-called ethics is the behavior relationship norms between human beings, human beings and collective, society and environment. Ethics is mainly through three aspects to play a role, one for public opinion environment, two for traditional customs, three for people ' s own beliefs. Business ethics has another name, called corporate ethics. The socalled enterprise ethics refers to the enterprise, the enterprise establishment unit as a main body, the enterprise, the enterprise establishment unit in the daily management activities of the ethical concept as a core. The scope of its research includes internal and external scopes. The complex ethical relationship between internal management and external stakeholders requires some corresponding ethical norms and moral norms to constrain and implement.

\subsection{Accounting Professional Ethics}

The professional ethics of China's accounting personnel are clearly stipulated in laws and regulations such as China's Accounting Law and Accounting Basic Work Standards. These laws and regulations are summarized as the following 8 points: dedication, honesty and trustworthiness, integrity and self-discipline, objective and fair, adherence to guidelines, improvement of skills, participation in management, and strengthening of services. The Ministry of Finance 's ' Guiding Opinions on Strengthening the Integrity Construction of Accountants ' (Finance and Accounting No.9) further expresses the accounting professional ethics. The ultimate goal of these documents and policies is to achieve the policy of ' credibility and honor, dishonesty and shame ', to avoid financial fraud and other improper behavior.

\section{Review of the Citic Case}

\subsection{Company Profile}

In 1997, A-share listed company, CITIC Guo' an Information Industry Co., Ltd. (hereinafter referred to as CITIC Guo' an) was listed on the Shenzhen Stock Exchange. His parent company was CITIC Guo' an Co., Ltd. (hereinafter referred to as CITIC Group), and the holding proportion of the parent company was $100 \%$. In 2003, CITIC invested 
CNY 4.2 billion to participate in the resource development of Qaidam Basin in Qinghai. Qinghai CITIC Guo' an Science and Technology Development Co., Ltd. is a subsidiary of CITIC Guo' an Group, and he has the mining right to the West Tai Jinar Salt Lake. In 2004, Qinghai CITIC Guoan Technology Development Co., Ltd. (hereinafter referred to as Qinghai CITIC Guoan) became a member of CITIC Guoan and a subsidiary of CITIC Guoan. Now the company 's main industry for China ' $\mathrm{s}$ national security radio and television business, dedicated to Internet projects in the basic business of cable television networks and satellite communications to provide investment.

\subsection{Overview of Financial Fraud}

On 3 March 2021, the CSRC sent a ' advance notice of administrative punishment ' to CITIC Guoan, which concluded that CITIC Guoan had false records in its annual financial statements for seven consecutive years from 2009 to 2015 , with a cumulative false profit of 1.013 billion yuan. Further, the SFC intends to decide: First, request the CITIC Security Order to correct and give warning; 2. And a fine of600,000yuan; 3. Sun Yalei and other nine relevant persons were warned, and as the responsibility were imposed a fine of50,000-300,000yuan. After the falsification event was discovered by the CSRC, the stock price plummeted, public opinion broke out, and criticized.

\subsection{Analysis of CITIC 's Financial False Means}

\subsubsection{Fiction Business, Ambitious}

In April 2009, Qinghai CITIC Guoan held a sales conference, it is expected that the year may be completed sales revenue of about 400 million yuan, it is difficult to complete the budget sales target of 1 billion yuan, in order to complete the sales target, choose to use pre-sale method to complete the performance, at the same time in accordance with the $10 \%$ price concessions and the same period commercial loan interest rate to pay customer interest in advance payment.

How to achieve 600 million huge gully? Enterprises will inevitably take risks, so they will falsify, inflate income and reduce financial costs to achieve the purpose of sales revenue. Qinghai CITIC Guoan received customer pre-sale money, its accounting treatment is : loan : bank deposits ( or receivables ), loan : pre-paid accounts. At the same time, artificially inflated income from sales contracts and warehouse receipts of fictitious goods is processed as follows: borrowing: accounts receivable, and lending: main business income. At the end of the month, the two subjects of pre-paid accounts and accounts receivable are debited and written off to balance the accounts.

\subsubsection{The Virtual Increase of Income}

During 2004-2009, after 10 customers such as China Agricultural Group Holdings Co., Ltd. paid advance payments to the company, the company not only did not provide all the actual supply, but also synchronized the nonactual shipment part into the book income. Finally, CITIC Guoan financial report showed that the cumulative virtual increase in income of 506 million yuan in 2009-2014.

\subsubsection{Understated Expenditure and Undercharged}

In the pre-sale contract of Qinghai Zhongxin country, the cost of undelivered goods accounts for $12 \%-15 \%$ of the total cost. During the period of inclusion of CITIC Guoan's consolidated financial statements, the cumulative "Omitted" financial expenses for 2009-2014 amounted to 507 million yuan.

\subsubsection{Inflated Performance, ' Lift ' the Stock Price}

During 2009 - 2014, Qinghai CITIC Guo ' an was included in the consolidated statement of CITIC Guo ' an, with a cumulative virtual increase of CNY 506 million in operating income, a cumulative decrease of CNY 507 million in financial expenses, and a cumulative total of CNY 1013 million in profit. In 2014, CITIC Guoan 's stock price began to skyrocket, rising from about 6 yuan / share in January, doubling at the end of the year, and even exceeding 30 yuan / share in June 2015.

\subsubsection{False Records, Misleading Information}

Due to book inflated income and less financial expenses, there are false records in the ' 2015 Annual Report ' disclosed by CITIC Guo 'an. The result is that the net profit from January to June 2015 was inflated by 68 million yuan, resulting in CITIC Guo 'an 's book investment income in 2015 million yuan, accounting for $6.24 \%$ of CITIC Guoan 's investment income and $8.56 \%$ of the total profit.

\subsubsection{False Opinions, Help Zhou}

The financial report of citic Guoan was audited by jingdu tianhua accounting firm for the first three years, that is, from 2009 to 2011, and the last four years were audited by zhitong accounting firm. However, without exception, for seven years, without exception, the standards issued by both firms have no reservations.

\section{Analysis of CITIC 's Financial Fraud}

\subsection{The breach of Business Ethics by Citic Guoan}

The case shows that CITIC Guoan in order to achieve its 1 billion sales target, a large number of pre-sale contracts with customers, making a substantial increase in revenue. The company carries on the financial falsification with the false method, has obviously violated the enterprise business ethics to abide by the principle of honesty and trustworthiness. Its listing seven years, year by year through false income, create a company thriving illusion, deceive thousands of shareholders. According to statistics, in the $1920 \mathrm{~s}$, the number of CITIC Guoan investment was about 200,000, with an average of about 50,000 yuan per person. This behavior has seriously damaged the interests of investors. Although it can allow companies to gather large amounts of money in a short period of time, it violates the business ethics of enterprises and blindly takes benefit as the foundation. It is impossible for CITIC to develop sustainably.

\subsection{The Breach of Accounting Professional Ethics by CITIC Guoan}

In this case, the auditors violated the principle of audit discretion. It does not strictly follow the professional standards and regulations of the audit, and does not maintain the necessary professional caution on its working procedures. The company signed such a large amount of pre-sale contracts with dozens of customers, the audit did not catch up with the source, just go through the process, go through the field. For the cumulative inflated income of hundreds of millions, as auditors, they should be highly sensitive to their large data, rather than simple reconciliation. After CITIC Guoan management violates the business ethics, further pressure on 
financial personnel not only violates the accounting standards, but also violates the professional ethics, financial fraud, and ultimately on the road, hurt.

\section{Inspiration and Thinking of CITIC Guoan Financial Fraud}

CITIC Guoan through inflated income, less financial expenses and false statements and other financial fraud means to inflate profits to complete the business performance objectives and stock price stability objectives. After the financial fraud incident, the company 's stock price has been in doldrums for a long time, and in recent years it has fallen to about 2 yuan / share. November 30, 2017, 14.3 yuan / share, total market value of 48 billion yuan. Until June 7,2021, it closed at 2.23 yuan / share, with a total market value of 8.741 billion yuan. Only three years, the stock price evaporated nearly 40 billion yuan, down more than $84 \%$. According to Choice Financial Terminal data, on March 31,2010, the number of CITIC Guoan shareholders was 185 thousand on April 30, 2020, the number of shareholders was 210,000 ; on December 31, 2017, the maximum number reached 261,000 households. This means that there may be hundreds of thousands or even more than two hundred thousand shareholders impaired interests. It can be seen that direct stakeholders such as small shareholders and investors of the company have suffered huge losses and have a wide impact.

The incident so that the company' $\mathrm{s}$ credibility and reputation plummeted for future development of the company overshadowed. According to relevant reports, some investors will pick up legal weapons and ask the company to compensate for losses. It can be seen that the harm of violating business ethics and accounting professional ethics is huge. The victims may be tens of millions of individuals, enterprises that abide by business ethics, and more likely the credibility of listing. To enhance business ethics and accounting professional ethics, I have the following thinking.

\subsection{Strengthening the Cultivation of Professional Quality of Operators}

Man is the most active factor. Whether the daily accounting and financial management of the enterprise can reflect the accounting information fairly and objectively, and whether it can have a legitimate, reasonable and realistic supervision and decision-making on the daily economic business, these key points depend on whether the accountants have handled the daily economic business in strict accordance with laws, regulations and rules. It can be seen that accounting professional ethics runs through the whole financial management work, and is implemented in all aspects, all fields and the whole process. Its realization relies firmly on the inner world of the staff themselves, whether selfdiscipline, whether in place, and whether in accordance with the rules. Management, including administrative departments, group (company) management should strengthen the management personnel, especially in the financial integration, strengthen the implementation of the internal control system, follow the professional ethics, keep the bottom line, do not step on the mine, do not cross the line.

\subsection{Strengthening the Construction of Business Ethics and Accounting Professional Ethics System}

After decades of development, China has formed a basic system of financial business ethics and accounting professional ethics based on ' accounting law ' and ' accounting standards ' as the highest level and ' accounting basic work norms '. We should implement the new development concept, integrate into the new normal, further enrich the theoretical system of business ethics and accounting professional ethics, and become a useful supplement to laws and regulations.

\subsection{Improve the Threshold of Illegal Punishment}

Financial fraud is like a malignant tumor, which is deeply long in the world economic environment, including China 's economy and society. It can not be waved and cut continuously, and seriously damages the interests of investors and creditors. The reason is that the soil it grows is too " fertile" : obtaining high illegal interests at low illegal costs. Therefore, the administrative department should increase the intensity of illegal punishment.

In this case, according to the " penalties, " factor companies in 2009 to 2015 during the existence of false profits, false disclosure and other acts, the company was fined 600,000 yuan, several executives were liable to a fine of 5-300,000 yuan. According to the time of fraud, this punishment is still carried out according to the 2005 edition of the Securities Law, which is actually a top-notch punishment. Even so, compared to the false profit up to 1 billion yuan, it seems still low, for investors is a kind of " ridicule " and " insult. " And its shares are still in circulation. Punishment, increased peer visits, it is difficult to form a dare not to falsify, unwilling to falsify, can not falsify the situation, it is difficult to eradicate.

\subsection{External Supervision Should Be Deepened}

Trust does not mean oversight, CITIC security fraud, the length of time, the amount of large, a blatant. Just seven years ago, the amount of fraud was as high as 1 billion yuan, audit institutions are pretending deaf ? Or blind ? It 's hard to understand. And it is worth mentioning that, with the accounting firm, Beijing Kyoto Tianhua accounting firm, Beijing Tianhua accounting firm, Beijing Kyoto accounting firm and other four firms in 1999-2020 rotation for the CITIC security audit office, after inspection, these four are in line, the essence remains unchanged, but the name of the unit change. The accounting firm, whose name has changed year by year, is also strikingly fined. Since 1999, CITIC Guoan audit, although on the surface in the replacement of firm audit, but in fact these four firms are the same firm, just after a series of institutional reforms, renamed merger. That is to say, for the entire seven years ( longer actual time ), CITIC Guoan has been changing soup without changing medicine, is still an audit firm. Serious violation of relevant provisions. Therefore, the lack of external supervision is also one of the important causes of financial fraud, should attach great importance to.

\section{References}

[1] China Securities Regulatory Commission Administrative Penalty Decision ( CITIC Guoan Information Industry Co., Ltd., Sun Yalei, etc. ) No.36.

[2] Shi Ruo, Gao Xiaolin. Wanfu Biotechnology financial fraud case analysis-based on the perspective of business ethics and professional ethics [J].China management informatization, November 23, 2020, 21.

[3] Yang Huidan. Research on Financial Fraud in Listed Companies - From the Perspective of Business Ethics and 
Accounting Professional Ethics $[\mathrm{J}]$. Investment and

Cooperation, 2021 (03). 